SPENCER, R. (1955). J. gen. Microbiol. 13, 111-118.

\title{
The Taxonomy of certain Luminous Bacteria
}

\author{
BY R. SPENCER* \\ Torry Research Station, Food Investigation Organization, Department \\ of Scientific and Industrial Research, Aberdeen
}

\begin{abstract}
SUMMARY: A named strain of each of the species Photobacterium phosphoreum, $\boldsymbol{P}$. fischeri, $\boldsymbol{P}$. albensis, $\boldsymbol{P}$. pierantonii, $\boldsymbol{P}$. splendidum, $\boldsymbol{P}$. sepia and $\boldsymbol{P}$. harveyi, together with a recently isolated strain of each of the first two named species, were studied in an attempt to elucidate their correct generic classification. On the basis of morphology, sensitivity to certain antibiotics and a vibriostatic substance, and method of dissimilation of carbohydrates, it was concluded that $P$. sepia and $P$. harveyi should be classified in the genus Aeromonas, and the remainder of the species in the genus Vibrio.
\end{abstract}

Although there have been many studies of the mechanism of light production by luminous bacteria (Harvey et al. 1948), comparatively few have been devoted to the taxonomy of this group. The work done has been complicated by the fact that these organisms belong to the large group of Gram-negative, non-pathogenic, non-pigmented rods whose differentiation has always been a difficulty. The Dutch workers, following the lead of Beijerinck (1889), classify all luminous bacteria in the genus Photobacterium regardless of their differences. This practice has much to commend it from the determinative viewpoint, but it may result in bacteria which belong to different morphological groups being classified together. In Bergey's Manual (1948) Iuminous bacteria are placed in the genera Pseudomonas, Vibrio and Bacterium. As the latter scheme bases the differentiation between $P$ seudomonas and Vibrio upon presence or absence of curvature in the bacterial cell, a very variable characteristic, and as the genus Bacterium in the Manual is an acknowledged collection of unrelated groups, it does not clarify matters. A recent paper by Breed \& Lessel (1954) reviewed the literature on the nomenclature of luminous bacteria, but presented no new facts concerning their taxonomy. In recent years, new criteria have been evolved for the differentiation of certain groups of Gram-negative rods, notably the significance of the type of carbohydrate dissimilation (Hugh \& Leifson, 1953), and the inhibition by various antibiotics (Shewan, Hodgkiss \& Liston, 1954). This paper records the results of applying these and other criteria to a number of strains of luminous bacteria, as part of a general study of the bacterial flora of marine fish, of which luminous bacteria form a not inconsiderable part (Stewart, 1932; Aschehoug \& Vesterhus, 1943; Thjøtta \& Sømme, 1943; Liston, 1955).

* Present address : Humber Laboratory, Food Investigation Organization, Dept. of Scientific and Industrial Research, Wassand St., Hull. 


\section{METHODS}

One strain of each of the species Photobacterium phosphoreum, P. sepia, $\boldsymbol{P}$. albensis, $\boldsymbol{P}$. pierantonii, $\boldsymbol{P}$. harveyi and $\boldsymbol{P}$. splendidum were obtained from Professor A. J. Kluyver of Delft. One strain of $\boldsymbol{P}$. fischeri was obtained from Professor J. Cruickshank of Aberdeen University. Strain 2 was isolated from the gut contents of skate and is representative of over fifty almost identical strains obtained from North Sea fish and classified as $P$. phosphoreum. Strain 64 was obtained from the gut contents of mackerel and is classified as $\boldsymbol{P}$. fischeri.

The solid media used consisted of tap-water Lemco agar (Lemco, $10 \mathrm{~g}$.; peptone (Oxoid), $10 \mathrm{~g}$.; $\mathrm{NaCl}, 5 \mathrm{~g}$., tap water, $1000 \mathrm{ml}$; pH 7.6) and sea-water Lemco agar (Lemco, 10 g.; peptone, $10 \mathrm{~g}$.; tap water, $250 \mathrm{ml}$.; aged sea water, (ZoBell, 1946), $750 \mathrm{ml}$; pH 7.6). Tap-water peptone water (peptone, $10 \mathrm{~g}$.; $\mathrm{NaCl}, 0.5 \mathrm{~g}$; tap water, $1000 \mathrm{ml}$; $\mathrm{pH} \mathrm{7.6)}$ or sea-water peptone water (peptone, $10 \mathrm{~g}$; t tap water, $250 \mathrm{ml}$; ; aged sea water, $750 \mathrm{ml}$.; $\mathrm{pH} \mathrm{7.6)}$ ) were used for liquid media. For the biochemical tests tap-water media alone were used as it was found that these gave good growth in all cases.

For the antibiotic sensitivity tests, tap-water Lemco agar was used as sea water inhibited the action of terramycin to some extent. Tablets containing the indicated amounts of antibiotic were used for penicillin, chloramphenicol, streptomycin and terramycin, and the cup assay method with a saturated aqueous solution for the vibriostatic substance $0 / 129$ (2-4-diamino, 6-7-diisopropylpteridine; Shewan et al. 1954). The agar plates were surface-poured with a young culture and dried at room temperature for some hours before the antibiotics were applied.

In the determination of the type of dissimilation of carbohydrates, Hugh \& Leifson's (1953) medium was used, but with $1.5 \% \mathrm{NaCl}$ instead of $0.5 \%$. Glucose was the only carbohydrate used as Hugh \& Leifson found that organisms which oxidize glucose, but do not ferment it, do not ferment other carbohydrates.

Unless otherwise stated, the temperature of incubation was always at $20^{\circ}$.

Observations on morphology were made on cultures growing on tap-water and sea-water Lemco agar, and in tap-water and sea-water peptone water, at various temperatures, using stained preparations, and also wet preparations by phase-contrast microscopy. Determinations of motility were made on cultures growing in tap-water and in sea-water peptone water, again at various temperatures.

The methods used for the biochemical tests are given in the appropriate column in Table 1. Sugar fermentation and gelatin liquefaction tests were examined up to 28 days of incubation, and the following sugars were used: glucose, lactose, sucrose, mannitol, maltose, starch, glycerol, inositol, rhamnose, xylose, inulin, galactose, glycogen, raffinose, arabinose, sorbitol. The Voges-Proskauer, methyl red, indole production, and nitrate reduction tests were examined after 7 days, and the trimethylamine-oxide reduction test after 9 days of incubation. The trimethylamine-oxide reduction test was used as an 
index of possible importance in fish spoilage. Growth temperatures were determined after $72 \mathrm{hr}$. of incubation in peptone water, with tap water for Photobacterium albensis and sea water for the other strains.

\section{RESULTS}

The cultural and biochemical characteristics of the strains of luminous bacteria were first determined (Table 1) and compared with previously published characteristics, notably those in Bergey's Manual (1948), in Warren's (1945) study of several species of luminous bacteria, in the original description by Johnson \& Shunk (1936) of Photobacterium harveyi, and a full description of $\boldsymbol{P}$. fischeri. This was necessary to ensure the validity of the named strains and the correct identification of the two unnamed strains.

There appeared to be several differences between the characteristics found in the present study and those previously described. Besides slight anomalies in the production of acid in various sugars, particularly the inability of strain 2 , Photobacterium harveyi and $\boldsymbol{P}$. phosphoreum to produce acid in sucrose, the main discrepancies were the inability of $\boldsymbol{P}$. fischeri and $\boldsymbol{P}$. pierantonii to liquefy gelatin, of $\boldsymbol{P}$. splendidum to grow at 30 and $37^{\circ}$, and the non-motility of $\boldsymbol{P}$. albensis and $\boldsymbol{P}$. pierantonii. These discrepancies will be discussed later.

The antibiotic sensitivity patterns are shown in Table 2 . According to the classification of Shewan et al. (1954), Photobacterium albensis should be classified as a member of the Achromobacteriaceae because it shows sensitivity to penicillin and to streptomycin. However, the previously described single polar flagellation of this organism and its morphology, vibrio- or spirillum-like, would preclude this classification. Also, as the degree of inhibition is very slight, much less than is generally obtained with tested members of the genus Achromobacter, it is considered that Photobacterium albensis, like the others, should be placed in the family Pseudomonadaceae. Within this family the species fall into two groups, those sensitive to the vibriostatic compound $\mathrm{O} / 129$, and those (P. sepia and $P$. haveyi) which are insensitive.

The method of dissimilation of glucose by the various species was in every case fermentative, thus confirming the results of Doudoroff (1942).

The criterion generally used for differentiating the genera Pseudomonas and Vibrio is that of curvature of the cell, which is present in vibrios and absent from pseudomonads. Consequently, the morphology of the various species was investigated in liquid and on solid media. It immediately became apparent with Photobacterium phosphoreum and strain 2 that there were marked discrepancies between previously published descriptions and those now observed. Beijerinck (1889), Stewart (1932), Warren (1945) and Bergey's Manual (1948) all emphasized the coccal or coccobacillary morphology of $\boldsymbol{P}$. phosphoreum, but unfortunately none gave the medium used, although Beijerinck did record that they 'prendre dans certaines conditions la forme de spirilles et de vibrions'. Liston (personal communication) has pointed out that although $\boldsymbol{P}$. phosphoreum is coccal or coccobacillary when grown in both tap-water and sea-water peptone water, on tap-water Lemco agar vibrio- and spirillum-like 


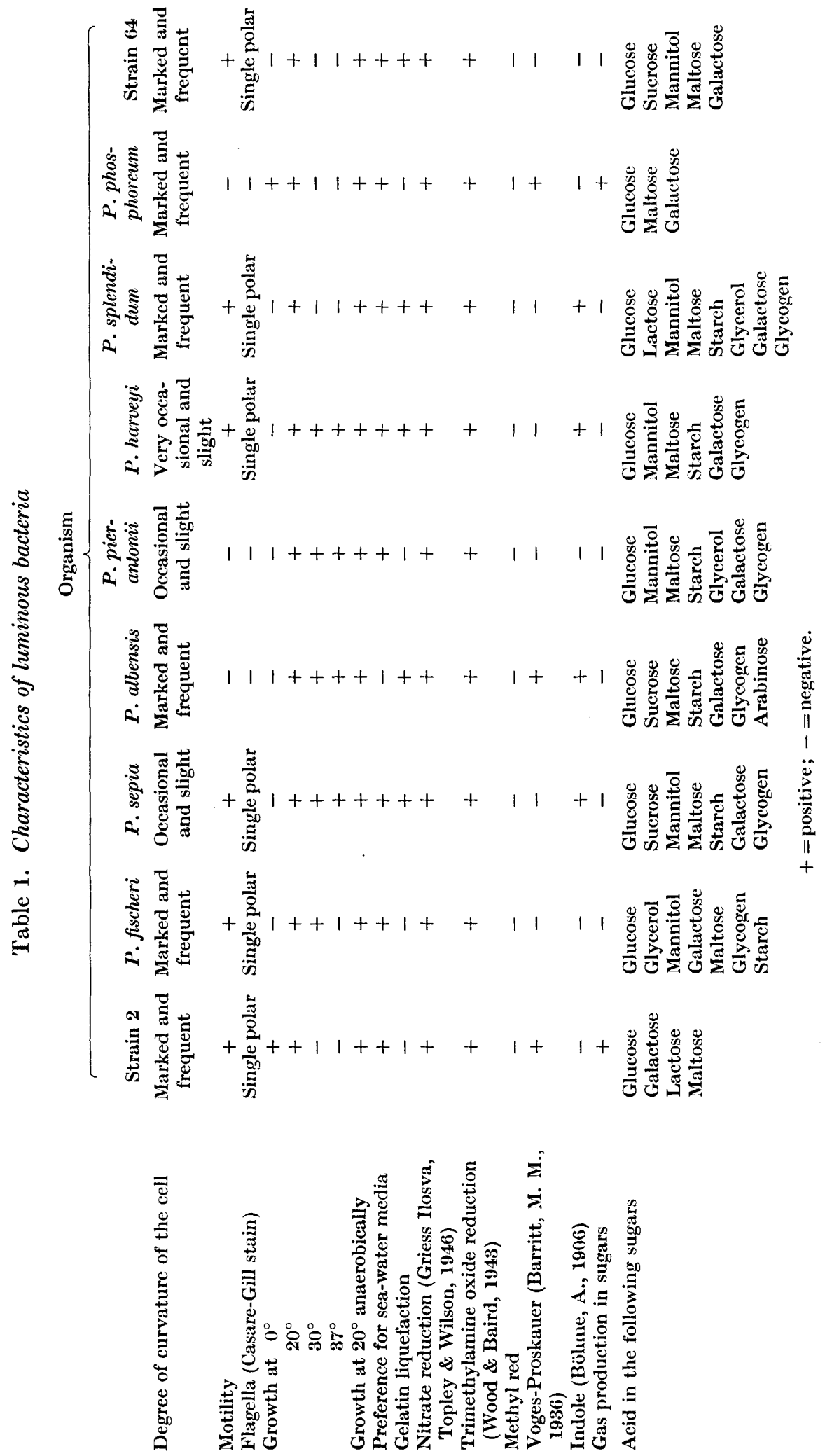


forms are produced. This observation has been confirmed and extended to sea-water Lemco agar (Pl. 1, figs. 1-3). The presence or absence of curvature in the cells of the other species is recorded in Table 1, and typical appearances are shown in Pl. 1, figs. 4-6.

\section{Table 2. Sensitivity of luminous bacteria to antibiotics}

\begin{tabular}{|c|c|c|c|c|c|}
\hline Organism & $\begin{array}{c}\text { Penicillin, } \\
\text { 2.5 i.u. } \dagger\end{array}$ & $\begin{array}{l}\text { Chloram- } \\
\text { phenicol, } \\
100 \mu \mathrm{g} . \dagger\end{array}$ & $\begin{array}{c}\text { Strepto- } \\
\text { mycin, } \\
80 \mu \mathrm{g} . \dagger\end{array}$ & $\begin{array}{c}\text { Terramycin, } \\
10 \mu \mathrm{g} \cdot \dagger\end{array}$ & $\begin{array}{l}\text { Vibriostatic } \\
\text { compound } \\
\text { o/129* }\end{array}$ \\
\hline Strain 2 & - & + & + & + & + \\
\hline P. fischeri & - & + & + & + & + \\
\hline P. sepia & - & + & + & + & - \\
\hline$P$. albensis & $\mp$ & + & + & + & + \\
\hline$P$. pierantonii & - & + & + & + & + \\
\hline$P$. harveyi & - & + & + & + & - \\
\hline P. splendidum & - & + & + & + & + \\
\hline P. phosphoreum & - & + & + & + & + \\
\hline Strain 64 & - & + & + & + & + \\
\hline
\end{tabular}

+ , sensitive; - , insensitive; $\mp$, slight degree of sensitivity.

* 2-4-diamino, 6-7-di-isopropyl pteridine.

$\dagger$ See p. 112.

\section{DISCUSSION}

Certain discrepancies have been noted between characteristics of the luminous bacteria examined, and previous descriptions in the literature. Both Photobacterium fischeri and $\boldsymbol{P}$. pierantonii were found not to liquefy gelatin, although the recently isolated strain closely resembling $P$. fischeri does liquefy gelatin. P. fischeri was recorded by Johnson \& Shunk (1936) and by Warren (1945) as liquefying gelatin only weakly, Bergey's Manual (1948) recorded both Pseudomonas pierantonii and Vibrio pierantonii as not liquefying gelatin, whilst Warren (1945) recorded Photobacterium pierantonii as liquefying gelatin. Consequently, the discrepancies found are not thought important.

It is known that the ability to liquefy gelatin is frequently lost on continued subculture on artificial media, as is the property of motility which also appears to have been lost by the strains of Photobacterium pierantonii and $\boldsymbol{P}$. albensis studied. The lowering of the maximum growth temperature of $\boldsymbol{P}$. splendidum below $30^{\circ}$ may also come into the category of properties lost due to continued subculture in artificial media, particularly as the other characteristics of this species correspond to those previously published. Johnson, Zworykin \& Warren (1943) obtained electron micrographs of $P$. fischeri showing lophotrichous flagellation. In the present study this organism was found to possess a single polar flagellum. The difference may merely be due to the different methods of examination.

It thus appears that the strains of luminous bacteria studied are typical members of the named species. Also, although this is not the main purpose of the present work, it appears that the strains of the named species studied have sufficiently distinct characteristics to be regarded as separate species, with the possible exception of Photobacterium sepia and $\boldsymbol{P}$. harveyi. Previous work, 
notably by Warren (1945), together with the present work, has shown these species to be very similar.

A Gram-negative heterotrophic rod which is motile by one or more polar flagella, is easily classified in the family Pseudomonadaceae. If, however, the rod is non-motile, difficulties are immediately found, but by determining the antibiotic sensitivity pattern of the organisms these difficulties can generally be resolved. By this criterion, the non-motile luminous bacteria studied fall into the Pseudomonadaceae, and the classification of the motile species in this family on the basis of their polar flagellation is confirmed. Within this family the strains can only fall into the genera Pseudomonas or Vibrio, or possibly the genus Aeromonas (Kluyver \& van Niel, 1936). On the basis of curvature of the cell, it can be seen (Table 1) that some of the strains fall into the genus Vibrio, whilst the remainder, on this criterion alone, should be placed in the genus Pseudomonas. All those species showing marked curvature of the cell are also sensitive to the vibriostatic substance, and, as they evince a fermentative dissimilation of glucose, there seems no reason why they should not be placed in the genus Vibrio. These species are Photobacterium fischeri and strain $64, \boldsymbol{P}$. phosphoreum, and strain $2, \boldsymbol{P}$. albensis and $\boldsymbol{P}$. splendidum.

Photobacterium pierantonii shows only slight curvature, but is sensitive to the vibriostatic substance. Many strains of pigmented and non-pigmented pseudomonads, including some Aeromonas species, have been examined, and have all been found to be insensitive to the vibriostatic substance (Spencer $\&$ Hodgkiss, unpublished). Consequently, it is considered that despite its lack of marked curvature, $P$. pierantonii should be classified as a vibrio.

The two remaining species, $P$ hotobacterium sepia and $\boldsymbol{P}$. harveyi, due to their lack of curvature and resistance to the vibriostatic compound, cannot be placed in the genus Vibrio although they do dissimilate glucose fermentatively. Kluyver \& van Niel (1936) suggested that pseudomonads possessing a fermentative metabolism should be separated from those which possess an oxidative metabolism similar to that of Pseudomonas aeruginosa, the type species. For the group of fermentative pseudomonads they proposed the generic name Aeromonas, a suggestion which has been repeated by several subsequent workers. Photobacterium sepia and $\boldsymbol{P}$. harvey $i$ should fall into this genus, except that as originally defined by Kluyver \& van Niel, members of the genus should ferment carbohydrates with the production of carbon dioxide and hydrogen. Strains of non-luminous Aeromonas studied by the author have this property, but neither Photobacterium sepia nor $P$. harveyi produces gas from carbohydrates, or does so only in very small amounts (Doudoroff, 1942). Despite this, it is considered that these two species should be placed in the genus Aeromonas, the definition of which should be amended so as not to exclude anaerogenic fermentative pseudomonads. This would be preferable to creating a new genus on the present insufficient knowledge of the metabolism of pseudomonads.

As luminous bacteria have been shown to fall into two distinct genera, indeed, into two distinct tribes in the generally accepted taxonomic scheme, i.e. Pseudomonadeae and Spirillae, it is thought unwise to group them 
together in a common genus Photobacterium. The suggested generic classification of the luminous bacteria is that the species phosphoreum, albensis, pierantonii, splendidum and fischeri be placed in the genus Vibrio, whilst sepia and harveyi be placed in the genus Aeromonas. This classification is substantially the same as that proposed by Breed \& I essel (1954) who, however, proposed that luminous bacteria of coccal or coccobacillary form should be placed in a separate genus, Photobacterium. As $\boldsymbol{P}$. phosphoreum has been shown to be a curved rod on solid media, and, moreover, sensitive to the vibriostatic agent, this separation is considered unnecessary.

The work described in this paper was carried out as part of the programme of the Food Investigation Organization of the Department of Scientific and Industrial Research.

\section{REFERENCES}

Aschenoug, V. \& Vesterhus, R. (1943). Investigation of the bacterial flora of fresh herring. Zbl. Bakt. (2. Abt.), 106, 5.

Barritt, M. M. (1936). The intensification of the Voges-Proskauer reaction by the addition of $\alpha$-naphthol. J. Path. Bact. 42, 441.

Bergey's Manual of Determinative Bacteriology (1948), 6th ed. Edited by BreEd, R. S., Murrey, E. G. D. \& Hrtchens, A. P. Baltimore: Williams and Wilkins Co.

Beijerinck, M. W. (1889). Le photobacterium luminosum, bactérie lumineuse de la mer du nord. Arch. neerl. Sci. 23, 401.

Böнмe, A. (1906). Die Anwendung der Ehrlichschen Indolreaktion für bacteriologische Zwecke. Zbl. Bakt. (1. Abt. Orig.), 40, 129.

Breed, R. S. \& Lessel, E. F. (1954). The classification of luminescent bacteria. Leeurvenhoek ned. Tijdschr. 20, 58.

DoudorofF, M. (1942). Studies on the luminous bacteria. II. Some observations on the anaerobic metabolism of facultatively anaerobic species. J. Bact. 44, 461 .

Harvey, E. N., Anderson, R. S., Buck, J. B., Chase, A. M., Eyring, H. \& Johnson, F. H. (1948). Bioluminescence. Ann. N.Y. Acad. Sci. 49, 327.

Hugh, R. \& Leifson, E. (1953). The taxonomic significance of fermentative versus oxidative metabolism of carbohydrates by various gram-negative bacteria. J. Bact. 66, 24.

Johnson, F. H. \& Shunk, I. V. (1936). An interesting new species of luminous bacteria. J. Bact. 31, 585.

Johnson, F. H., Zworykin, N. \& Warren, F. (1943). A study of luminous bacterial cells and cytolysates with the electron microscope. $J$. Bact. 46, 167 .

Kluyver, A. J. \& van Niel, C. B. (1936). Prospects for a natural system of classification. Zbl. Bakt. (2. Abt.), 94, 369 .

Liston, J. (1955). A group of luminous and non-luminous bacteria from the intestine of flatfish. J. gen. Microbiol. 12, i.

Shewan, J. M., Hodgriss, W. \& Liston, J. (1954). A method for the rapid differentiation of certain non-pathogenic, asporogenous bacilli. Nature, Lond., 173, 208.

StEwart, M. M. (1932). The bacterial flora of the slime and intestinal contents of the haddock (Gadus aeglefinus). J. mar. biol. Ass. U.K. 18, 35.

Тнјøтта, Тн., \& Søмme, O. M. (1943). The bacterial flora of normal fish. Skr. norske VidenskAkad. 4, 1.

Topley and Wilson's Principles of Bacteriology and Immunity, 3rd ed. (1946). Revised by Wilson, G. S. \& Miles, A. A. London: Edward Arnold. 
Warren, G. H. (1945). The antigenic structure and specificity of luminous bacteria. J. Bact. 49, 547.

Wood, A. J. \& BAIRD, E. A. (1943). Reduction of trimethylamine oxide by bacteria. 1. The Enterobacteriaceae. J. Fish. Res. Bd Can. 6, 194.

ZoBeld, C. E. (1946). Marine Microbiology. Waltham, Mass.: Chronica Botanica Co.

\section{EXPLANATION OF PLATE}

Fig. 1. Strain 2, tap-water peptone water culture, $18 \mathrm{hr}$. at $20^{\circ}$, showing coccal and coccobacillary forms. $\times 768$.

Fig. 2. Strain 2, sea-water Lemco agar culture, $24 \mathrm{hr}$. at $20^{\circ}$, showing curved rods. $\times 768$.

Fig. 3. P. phosphoreum, sea-water Lemco agar culture, $24 \mathrm{hr}$., at $20^{\circ}$, showing markedly curved forms. $\times 960$.

Fig. 4. P. splendidum, sea-water peptone water culture, $72 \mathrm{hr}$. at $20^{\circ}$, showing curved rods. $\times 768$.

Fig. 5. P. albensis, tap-water peptone water, $18 \mathrm{hr}$. at $20^{\circ}$, showing markedly curved forms. $\times 768$.

Fig. 6. $P$. sepia, sea-water Lemco agar, $48 \mathrm{hr}$. at $20^{\circ}$, showing typical straight rods. $\times 768$.

(Received 19 January 1955) 
Journal of General Microbiology, Vol. 13, No. 1
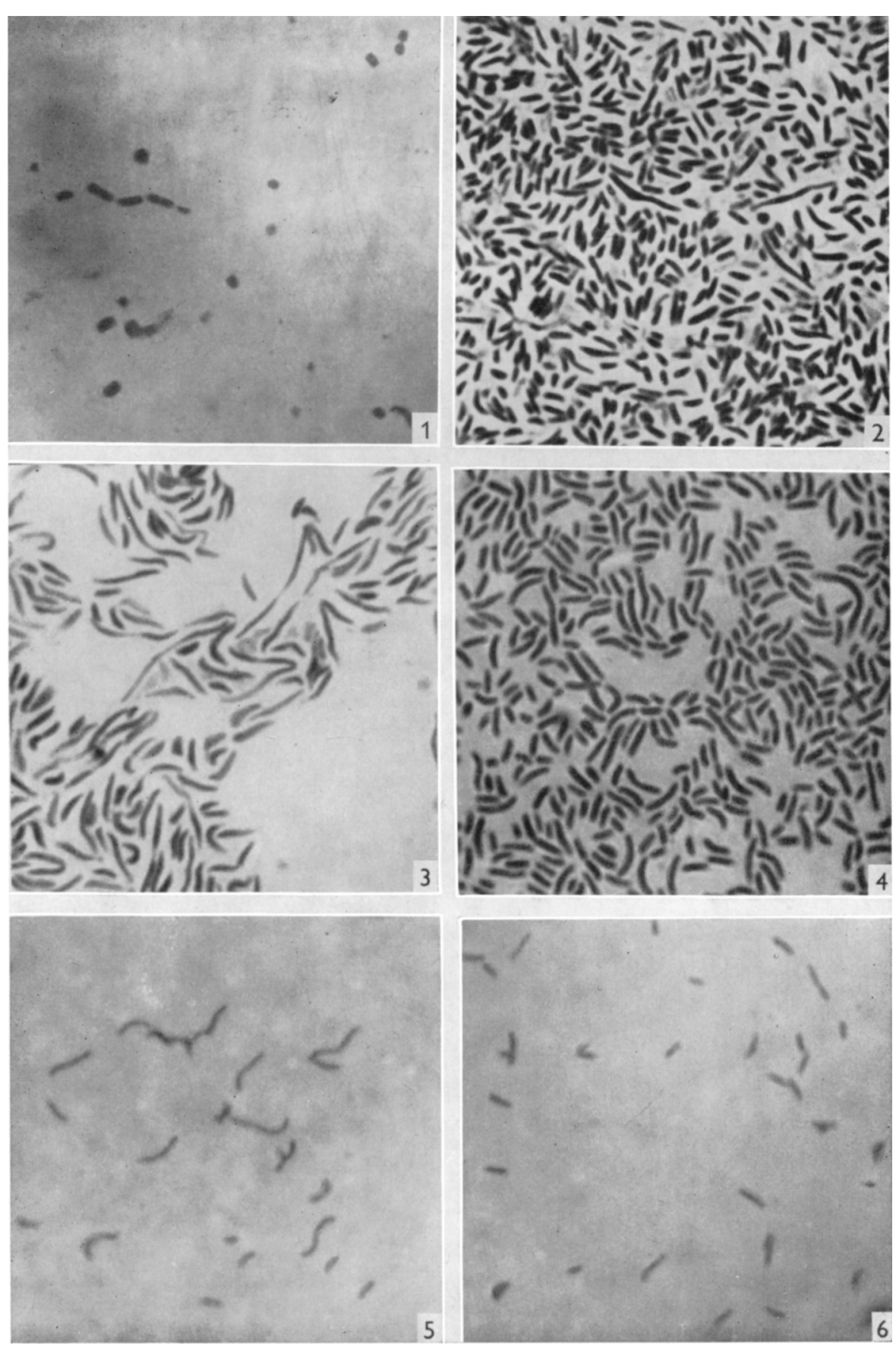

R. Spencer-axonomy of hinots bacteria. Piate 1 